\title{
PUBLIC/PRIVATE DIMENSION AND ITS REFLECTION ON THE CROATIAN HIGHER EDUCATION SYSTEM WITH REGARD ON THE GLOBALISATION PROCESS
}

\author{
Jelena Dujmović Bocka, PhD, Assistant Professor \\ Josip Juraj Strossmayer University of Osijek, Faculty of Law \\ Stjepana Radića 13, Osijek, Croatia \\ jdujmovi@pravos.hr
}

\begin{abstract}
The system of higher education is, most frequently, perceived as a part of public service which is justified by the fact it is commonly analysed from that point of view. Since the same system has recently been subjected to privatisation and commercialisation processes, it is of outmost importance to define the notion of public and private within the context of higher education, which is the main aim of this paper. Furthermore, it is necessary to place the higher education system within the framework of public and/or private and provide a thorough analysis of the dimensions relevant for all the interested parties in the domain of public administration, that is, its segment significant for the topic. The first part of the paper is, therefore, primarily focused on presenting the dimensions public/private to the interested parties, while providing relevant arguments regarding the topic, so valid approach in this segment of public administration is found by combining various interpretations. Some of the questions particularly interesting to the author are being discussed in the central part of the paper: in what way is the division on public/private evident in the Croatian higher education system, is higher education perceived as public service and to what extent is its development affected by the globalisation process? In the final part of the paper, certain conclusions are made based on the facts presented in the paper, which could be used for improving efficacy and effectiveness of the higher education system in Croatia.
\end{abstract}

Keywords: globalisation, public/private, public administration, public goods, public services 


\section{INTRODUCTION}

The debate about the public and private dimensions is quite frequently found in both domestic as well as foreign literature. Authors emphasize individual advantages along with the disadvantages of public and private in the context of higher education system. This paper sets the concept of public and private in the context of higher education system as public service.

Fundamental research questions are: in what way is public and private evident in the higher education system, is higher education considered a public service and to which extent do globalisation processes influence the higher education system? The following text should provide the answers to these questions.

Many authors have discussed and researched this topic. In their "Administrative Science - public administration in modern European context" Koprić et al. present the overview of the chapter Public Services - services of general interest, which has significantly contributed to this research paper. ${ }^{1}$ In his article "Social services in the concept of services of general interest" Đulabić explains the evolution of "services of general interest" (highlighting their features, fundamental characteristics and classification). ${ }^{2}$ Menger deals with the differences in the approach of public and private organisations. In his article The development of understanding the "transparency" of the organisations in the organisational theory Menger distinguishes between four approaches of defining "transparency" of organisations: formal, dimensional, normative and integrative approach. ${ }^{3}$

The aim of the paper is to indicate the existence of theoretical debate between the notions of public and private and to provide them with a suitable context within the higher education system. The essence of the paper is to research the perspectives of different authors regarding the topic with the aim of finding the most adequate perspective referring to the Croatian higher education system. In addition, the paper is focused on indicating various changes which have occurred

1 More in: chapter of the mentioned book - pages 215 to 244 . Author`s recommendation is to emphasize the significance of public services in law and politics of the whose analysis is presented in the same chapter with the following relevant subchapters: "Context of the dispute and fundamental dilemmas", "Services of general interest in the EU law", "Categories of services of general interest in law and politics of the EU. More in: Koprić, I. et al., Upravna znanost, Javna uprava u suvremenom europskom kontekstu, Pravni fakultet Sveučilišta u Zagrebu, Studijski centar za javnu upravu i financije, Biblioteka Suvremena javna uprava, Knjiga br. 25, Zagreb, 2014, pp. 215 - 244

2 More in: Đulabić, V., Socijalne službe u konceptu službi od općeg interesa, Revija za socijalnu politiku, vol. 14, no. 2, Zagreb, 2007, pp. 137 - 162, [https://hrcak.srce.hr/30325], accessed 25. May 2020

3 See: Menger, M., Razvoj shvaćanja "javnosti” organizacija u organizacijskoj teoriji, Zbornik Pravnog fakulteta Sveučilišta u Rijeci, vol. 39, no. 2, Rijeka, 2018, pp. 989 - 1009, [https://hrcak.srce. $\mathrm{hr} / 204643]$, accessed 25. May 2020 
within the system and researching the scope of their effects on the perception of higher education system as a public service.

Scientific methods used in the paper are the analysis and synthesis method, the abstraction and concretisation method, method of generalisation and specialisation, the classification method and the descriptive method. The paper is divided into five main chapters containing subchapters. The list of used literature is provided in the end of the paper. Individual approaches in the higher education system are described in the initial part of paper. The central part of the paper refers to the globalisation process and its influence on the higher education system. Changes and modifications within the system are discussed in the final part with emphasis on public-private partnership. Author's conclusions regarding the topic are presented in this part as well.

\section{FINDING THE ADEQUATE APPROACH REGARDING THE NOTION PUBLIC/PRIVATE BY COMBINING TWO INTERPRETATIONS}

The definition of public goods from the neoclassical economic perspective, as is pointed out by Samuelson (1954), refers to goods (or services) that are non-competitive and non-excludable. According to Samuelson, public goods are non-competitive since they cannot be consumed by an infinite number of users, without being exhausted. On the other hand, the same goods are non-excludable since the benefits cannot be limited to individual users. Many goods possess either one or the other quality and can be described as "partially public" goods (e.g. the notion of "social goods" has been applied to describe goods that are competitive, but non-excludable). ${ }^{4}$

The same author perceives private goods as goods that are both competitive and excludable. Samuelson also tried to naturalise the line between public and private. Goods are, according to Samuelson, basically described as either public or private

4 More in: Sandler 1999: 40-42, according to Marginson, S., The public/private divide in higher education: A global revision, Higher education, vol. 53, London, 2007, p. 311. Some of the chosen provisions of the Constitution of the Republic of Croatia will be emphasized here, such as art. 44 in which it is proscribed that every citizen of the Republic of Croatia has the right, under equal conditions, to participate in conducting public affairs and be administered in public service, then art. 66 proscribing that education is available to everyone, under equal conditions, according to their abilities, art. 67 that prescribes that under the conditions prescribed by law it is possible to establish private schools and universities and art. 68 in which the autonomy of universities and their independent decision-making process regarding their organisation and performance in accordance with the law is guaranteed. See: The Constitution of the Republic of Croatia, Official Gazette No. 56/90, 135/97, 08/98, 113/00, $124 / 00,28 / 01,41 / 01,55 / 01,76 / 10,85 / 10,05 / 14$ 
(determined according to the nature of the goods or service itself). Samuelson presumes that the market is the norm, that the market domain is non-state, in other words, private thus declaring public or partially public goods the exception from the norm itself. His approach has become dominant in neoclassical economics and has been absorbed into the matrix of neo-liberal way of thinking about public politics. Another concept resulting from economics is the one about the influence of side effects i.e. expansion. The ideas which originated from the economics of excludability, rivalry, insufficient production of public goods on the market and side effects are considered extremely useful and can, in more than one way, improve the understanding of higher education (neoclassical economic theory does not offer all the answers regarding public and private goods). ${ }^{5}$

Marginson claims that the opinion of some economists is useless since they perceive education as natural social good, a good that is non-competitive in its consumption, but primarily because its benefits can be limited to individuals. Some forms of education are competitive and not all benefits are excludable. The claim that education is essentially a social good does not justify the changeable character of higher education. Marginson observes that some aspects of education are more excludable or competitive than the others. Its production can be situated in two sectors - public and private. For example, thorough research published freely in public domain is not excludable, while secretive commercial research is more easily subjected to both competitiveness and excludability. It is far more useful to observe education as a potentially competitive or non-competitive, that is, potentially excludable or non-excludable good. In other words, unlike public or private character determined by internal nature of goods, public or private character of education presents a political choice. ${ }^{6}$

When it comes to political philosophy, public and private can lead to wider interpretations than those offered by economics, which has been evident in the text so far. For example, the notion "public" can refer to questions such as: how are the goods manufactured and by whom, who are they controlled by, how widely are they distributed, who benefits from them etc.? In this case, "public" can refer to collectively manufactured and/or consumed goods. Democratic philosophy claims "public" can be applied for widely available goods and/or goods manufactured in a transparent way, or goods whose production is the subject of mutual decision-making process within a community. In liberal political philosophy, however, the notion "public" is frequently related to government or state. The notion "private" refers here to any type of non-state production, for example, production

Cf. ibid., pp. 311-312

6 More in: Cf. ibid., pp. 312-313 
subjected to legal alienation/private property: the "market" in general, individual markets in specific sectors, home and family and similar. It is evident that the use of the prior mentioned notions is loose and eclectic and indicates the necessity for consistent definitions. ${ }^{7}$

Furthermore, traditional approaches to public/private offer two interpretations. Both are dualistic in a sense that they treat public and private as two mutually exclusive notions. The one is the economics notion of public/private that connects private with unnatural market. The other is the state notion of public/private that connects public with government or state. Both perspectives reflect individual political demands of economic liberalism oriented towards the market (private side of the duality); and social democracy oriented towards state institutions (public side of the duality). However, both are flawed. The notion of public/private, as defined by neoclassical economic theory, treats public and private as natural and universal attributes (it contains implicit biasedness in favour of high individualism and market forms of social organisation). The predicted efficiency is primary for economics and it presupposes market solutions. The neoliberal politician concludes that higher education is mainly a natural private good which should be marketized. ${ }^{8}$ Due to its instinctive inclination to market solutions, neoclassical economist tries to reduce or conceal the potential for side effects and collective goods in higher education. ${ }^{?}$

The occurrence of individualised side effects is also present. When providing political advice, neoclassical economist focuses on the possibilities for measuring or altering the market competition in higher education ${ }^{10}$, in addition to having the tendency to ignore or overshadow the options which increase the production of most of public goods. ${ }^{11}$ The notion of private/public defined in a state sense is equally useless since the concept of public as government or state: 1) underestimates the independent capacity of individual leading universities to shape their economic and social features through non-market activity such as global research cooperation, 2) neglects the possibilities of the universities formally owned by state to sell diplomas to international students on commercial basis, acting as a private company, 3) neglects the potential for collective goods and side effects

\footnotetext{
$7 \quad$ Cf. ibid., p. 313

$8 \quad$ Ibid.

9 Pusser, 2002, according to: Cf. ibid., p. 314

10 More about the conduct of people in administrative organisation in: Cvitan, O., Upravna organizacija, Veleučilište u Šibeniku, Šibenik, 2008, pp. 126-133. Moreover, it is the author`s recommendation regarding the terminological specification of the notion organisation to see more in: Blažević, R., Upravna znanost-kompendij, Pravni fakultet Sveučilišta u Rijeci, Rijeka, 2004, pp. 79-83

11 Marginson, op . cit. note 6, p. 314
} 
generated not in the government, but in citizens` associations, 4) etatism ignores the possibility of global public goods (considering the philosophical point of view in which the public = government; in the international sphere, where there is no government, the question arises regarding the way public goods have been produced). ${ }^{12}$

Etatism, in fact, treats higher education within a country/nation as public and state terrain, in contrast to cross-border higher education perceived as private and market terrain. Nationally, higher education is public, globally it is private. The etatist construct of global surroundings concurs with neoclassical economics. Even though they disagree regarding the national/state issue, both market economist and etatist perceive global surroundings as a relevant area of commerce. Marginson establishes that the alleged presents an impoverished perspective of global and a useless perspective of higher education. ${ }^{13}$

Koprić et al. emphasize that the quality of public administration ${ }^{14}$ has been questioned in theory and practice since the middle of the $20^{\text {th }}$ century and has gained importance during expansion of public services. It is claimed that certain improvements of quality and functioning of public administration are evident through regaining citizens' trust in government, state and its institutions, enhancing the image of public administration in public and similar, which the author greatly concurs with. ${ }^{15}$

When developing the wanted approach regarding the notion public/private it is necessary to extract the useful aspects from two areas, both the area of economics and political philosophy. According to Marginson, public goods are those that contain a significant element of non-competitiveness and/or non-excludability and are widely available to population. Public goods are the implicit biproducts of the "invisible hand". ${ }^{16}$

The interpretation of public/private leads to a conclusion that a combined approach regarding the described interpretations should be adopted in the area of

\footnotetext{
12 Kaul et al. 1999: 12, according to: Ibid.

13 Ibid.

14 It is recommended to see some of the chosen regulations relevant for higher education: Act on Quality Assurance in Science and Higher Education, Official Gazette, No. 45/09 and the Science and Higher Education Act, Official Gazette No. 123/03, 198/03, 105/04, 174/04, 02/07, 46/07, 45/09, 63/11, $94 / 13,139 / 13,101 / 14,60 / 15,131 / 17$

15 More about European perspectives of improving the quality of public administration in: Demmke, 2006, according to: Koprić et.al., Europski upravni prostor, Institut za javnu upravu, Zagreb, 2012, p. 201

16 Marginson, op. cit. note 9, p. 315
} 
higher education (it should be adjusted in accordance with the Croatian higher education system). Considering that private techniques and values nowadays occur more frequently in the public sphere, it is to be expected that in the near future along with the public higher education institutions there will be more private colleges (in Croatia there are already several private universities). It is consequently important to constantly point out the importance of interpretation of higher education as public service. Higher education should without a doubt belong to public sphere and be available to everyone under the same conditions (current research has shown that the privatisation and commercialisation processes are becoming more present in this important system).

\subsection{How is the modification of interpretations of public/private evident within the higher education system?}

The combination of public and private goods is determined by public politics, institutional managers and staff activities. As has been stated, it is not specified whether the emphasis is put on private or public goods intrinsic/inner nature of the goods (including the services), since this is a prior reached political decision. Whether the goods are manufactured and distributed through competitive market economy, is also a prior reached political decision. It is important not to forget the capacity of the politics creator to not only enhance market competitiveness, but also to take counter steps in order to expand the elements of non-competitiveness and non-excludability in both production and distribution - for example in higher education, expansion through distribution of benefits of study programmes and research findings. Non-competitiveness and non-excludability do not offer clear and simple solutions to all political problems. They are useful starting points for solving complex questions solved through politics and political issues. The same political issues may be related to both public and private goods. Different public and private goods may have differential influence within the population (for example, environment protection is a non-excludable and a non-competitive public good useful to everyone but at the same time it harms individual community members who benefit from ecologically harmful activities). When environment is protected, those persons acquire a non-excludable and a non-competitive public good (intact environment); they lose a part of the other public good which is non-excludable, but competitive under certain circumstances (economic freedom); and perceive "private as bad" compared to the first public good (loss of income). This example shows that public good does not exhibit unambiguous values and that it does not present the sum of public goods (political activities of 
enhancing public goods can include political confrontations as well as compromises between public and private goods). ${ }^{17}$

In the article "Managing natural resources as common goods: theoretical approach in differentiating public goods and common resources" Petak defines the notion of common (general) goods which in domestic legal literature are presented as general goods and are together with public goods treated as "general useable goods in general use". ${ }^{18}$ The article also refers to the notion of public goods which are as is stated "in the real-legal regime and in the property of individuals of public law". ${ }^{19}$ In his article "Is education a public good?" Petak presents several types of goods: private, club, common and public. He distinguishes two basic criteria: competitiveness in consumption and the possibility of exclusion of the non-payers from their consumption while emphasizing that the main feature of public goods is their non-competitiveness in consumption and inability to exclude the non-payers from their consumption. In his remarks, Petak questions whether it is possible to apply the term public good to higher education. He concludes that education possesses some features of private or club goods and it is therefore not possible to unambiguously specify it as a public good. ${ }^{20}$

In conclusion, there are different interpretations regarding the notions of public and private. Each system should be combined with the interpretation which

17 Cf. ibid., pp. 315-316. About personality traits and how to apply them in a team (especially useful for improving work in the area of higher education) more in: Tudor, G.; Srića, V., Menadžer i pobjednički tim, MEP Consult i Croman, Zagreb, 1996, pp. 41-43. The efficiency of higher education system is also considerably influenced by implementation of the so-called entrepreneurial ethics, more specifically principles applied within the framework of entrepreneurial ethics, more about the topic is available in: Bebek, B.; Kolumbić, A., Poslovna etika, Sinergija, Zagreb, 2000, pp. 69-75. The definition of public and private is presented in the following way: private goods are goods ,that can be parcelled out and made excludable, so that clear property rights can be attached to them", public goods are goods "that are non-excludable, meaning that the goods' effects (benefits or costs) are shared by everyone". More in: Kaul, I., Global Public Goods, A concept for framing the Post - 2015 Agenda?, p.10, [https:// www.ingekaul.net/wp-content/uploads/2014/01/Internetfassung_DiscPaper_2_2013_Kaul1.pdf], accessed 29. May 2020. The questions of public/private are thoroughly explained in two collections prepared by UNDP: "Global Public Goods" (Kaul et al. 1999) and "Providing Global Public Goods" (Kaul et al. 2003). Both point out the distributional aspects of "public" in various sectors and explore the potential of political mechanisms for increasing and regulating global public goods. See: Marginson, op. cit., note 13, p. 316

18 More in: Aviani, 2009., prema: Petak, Z., Upravljanje prirodnim resursima kao zajedničkim dobrima: teorijski pristup razlikovanju javnih dobara i zajedničkih resursa, Forum za javnu upravu - izazovi upravljanja javnim dobrima, Friedrich-Ebert-Stiftung, ured za Hrvatsku, Institut za javnu upravu, Zagreb, 2019, p. 10, [https://iju.hr/Dokumenti/fju_17.pdf], accessed 26. May 2020

19 See: Jug, 2004: 19, according to: Ibid.

20 More in: Petak ,Z., Je li obrazovanje javno dobro?, [http://www.rsp.hr/ojs2/index.php/rsp/article/ viewFile/877/773], accessed 26. May 2020 
mostly suits the current social atmosphere. In Croatia there are nowadays various public and private colleges offering different programmes. Many people support the notion that education should be public and available to everyone, however, this is not always the case. In order to achieve healthy competitiveness, it is essential to provide a wide choice of study programmes for students on both public and private colleges (the choice will depend on students' socioeconomic status). By accepting benefits and drawbacks of both types of studying the principle of equal availability will be fulfilled and students will be provided with equal opportunities when choosing a preferred university. Marginson`s claim that there is a necessity to establish an approach completely devoid of political and economic theorising is to be concurred with.

Higher education is exclusively public, private or combined. That, what has been produced, is a varying combination of public and private goods worldwide to the degree that public/private compose a positive sum (one can increase the other). Universities without state control are, therefore, producing certain private goods; while at the same time, even the most expensive private universities contribute to public goods, collective goods including their side effects. Even though public and private goods are mutually "heterogenous", they are produced within the same higher education institutions devoted to a wide range of teaching/learning, exploring, community and national service activities. This, however, does not imply that the public/private combination is everywhere always equally balanced (different public/private balance is one of the key elements distinguishing institutions from national higher education politics). Some institutions and national systems, primarily those in which higher education is organised as a market, put more emphasis on private goods than other institutions and systems. ${ }^{21}$

\section{GLOBAL/LOCAL PRIVATE/PUBLIC GOODS IN HIGHER EDUCATION}

Higher education is potentially competitive or non-competitive, excludable or non-excludable. It produces a complex and varying combination of public and private goods. Regimes of higher teaching may endanger equality of opportunity. Market forces strive to enhance competitiveness and excludability, while insufficiently ensuring the goods characterised as non-competitive and non-excludable. Pro-markets, ideologies and politics have the tendency to obscure the possibili-

21 Cf. ibid., pp. 316-317. The recommendation of the author is to further research the Agency for Science and Higher Education primarily using their official web page: [https://www.azvo.hr/hr/], accessed 19.March 2020 and to read more about the same topic in: Antić, T., Ustrojstvo i djelokrug javnog sektora, Pravni fakultet u Rijeci, 2014, p. 218 
ties and current issues of public goods. Insufficient recognition and insufficient production, however, do not eliminate public goods. Higher education market indicates the necessity of the politics designed in a way which enhances those public goods which create markets and it compensates for those public goods which the markets are trying to suppress and conceal from different perspectives and effects. ${ }^{22}$

Globalisation expands potential for both global private and public goods in higher education. The term globalisation implies expansion, deepening and accelerating of world connections. ${ }^{23}$ It is frequently connected with production of private goods through cross-border production and liberalisation of commerce within global financial system. Global co-dependence increases the scope of cross-border side effects whereby actions of one nation create benefits or expenses for other nations. Similarly, the development of global systems increases the potential of collective goods in a twofold sense of collective population (e.g. expanding the knowledge of public health issues) and collective nation (e.g. coordination of banking systems). This part of the study is based on Marginson's quote: "We all become too easily entrapped in understanding higher education in a sense of dual public/private ideology, and political horizon still bordered by a nation-country despite the obvious fertility of globalisation". ${ }^{24}$

Marginson's considerations indicate the following: a) neo-classical economists who implement the categories public/private in outcomes of higher education (public/private goods) instead of property (government sector/non-government sector) should be followed, neo-classical economists who privilege higher education markets on a national level and fail to understand public goods $s^{25}$ on a global scale should not, etatists who ignore the potential of private goods and the role of the market in national higher education, limit politics on a national level and fail to comprehend public goods on global scale shouldn 't be followed; b) when determining the nature of goods, irrelevant whether public or private, it is more important to determine whether they have been produced by market or by government or non-government sector, even though government institutions are more prepared to create politics than institutions in private property, institutions from both sectors produce public and private goods thus making both sectors available to politics being one of the two input units determining higher education; c) public and private goods are specific rather than universal attributes, goods produced

Cf. ibid., pp. 320-321

23 Held et al. 1999: 2, according to: $C f$. ibid., p. 323

24 Ibid.

25 More about public goods in general in: Antić, op. cit., note 14, pp. 83-98 
in higher education can be changed from public to private and vice versa while considering the fact that their position is historically determined and politically sensitive; d) public goods frequently include complex distributional questions, whereby one agent's public good is "public bad" or "private bad" of the other agent; e) tools are needed to enable complete understanding of private and public goods on a global scale and to link them with national systems and local higher education, global public goods in higher education are the key to more balanced, globally friendly, mutually useful, globally educated environment in which the contribution of higher education to development is increased; f) from the analytical point of view, tools to register cross-border side effects, such as "brain circulation" need to be developed; g) from the point of view of politics, units within the government focused especially on global side effects should be established on a national level, they could develop financial techniques thus enabling internalisation of side effects by identifying optimal national cross-border knowledge flows etc.; h) the approach to global public goods that are already available needs to be improved, particularly research, establishing national capacity in higher education in developing countries is the condition for wider circulation, admittance and production of knowledge, which in return establishes a better global balance; democratisation of planning and production of national and global public goods make them more transparent and encourage wider distribution while increasing their transparency; democratisation is achieved by making public goods explicit, by encouraging political debate and by involving numerous non-government agencies and participants. ${ }^{26}$

When taking Marginson's interpretation into consideration, following conclusion are to be drawn: there are two "streams" in the area of higher education, private and public. With the aim of achieving efficiency within the system of higher education, the administrative doctrine connecting the public sector with the private should be followed but to an extent acceptable to all the key participants within the higher education system. It is quite hard to acquire all the values and techniques from the private sector and to incorporate them into the public sector without having to disturb the interpretation of higher education as public service. It must be a service of common (public/social) interest. Market administrative reforms are trying to introduce market principles and methods in the public sector, which is preferable provided the traditional values are not completely abandoned.

26 Marginson, op. cit., note 19, pp. 330-332 


\subsection{Globalisation and national trends in higher education system}

With the aim of explaining unbelievable institutional and organisational similarities in social systems of countries around the world, "global institutionalists" (e.g. Meyer et al.,1997; Finnemore 1995) have for the last twenty years been debating about how have government institutions including state itself been modelled on "supra-national" level according to dominant values and processes of western ideology more than they have been modelled as autonomous and specific national creations. This perspective has been based on the idea that universal norms and culture shape national politics and political activities of national countries. Transnational accomplices such as UNESO, OECD, the World Bank and IMF support the idea of spreading global patterns and trends within the area of education. This is particularly true when taking teaching categories and the correlation model between the state and higher education into consideration. Perspective which includes regulation of government systems, including introduction of private higher education, might increase compassion of the institutions of higher education toward ecological pressures, whereby increasing overall efficacy of the system of higher education thus becoming a part of supranational agencies' ideologies (like e.g. World bank 1994). According to global institutionalists the guidelines of national educational system, in Dale's words, are "something more than performing informed scriptures, and accepting their legalisation on behalf of world ideologists, values and cultures". ${ }^{27}$ Dale opposes this approach by claiming that globalisation, ${ }^{28}$ when referring to education, is not merely a reflection of the western culture of education (cognitively based on values and norms which are spreading worldwide), but "a set of political-economic understandings for organisation of global economy, led by the necessity of detaining the capitalist system more than any other set of values." 29

Regardless of the perspective, that of global institutionalists or Dale's, it is clear, that current trends in higher education cannot completely be explained on the basis of national specificities. On the other hand, the growth of transnational trends such as mass production, return of expenses, regulation through deregulation, management, increase of stratification of the higher education system and increase in separating research and teaching functions. There is significant correspondence between the changes of political, institutional and academic patterns of produc-

\footnotetext{
27 Amaral A.; Magalhães A., Epidemiology and the Bologna Saga, Higher Education, 48, Issue 1, Springer, 2004, pp. 80-81

28 In that sense, it is interesting to read Kursar`s article in which he recounts Rosenberg's review of "globalisation theory”. More in: Kursar, T., Smrt „globalizacijske teorije “ili kraj još jedne revolucije?, Politička misao, vol. 45. no. 1, Zagreb, 2008, pp. 8-20

29 Dale, 2000:10, according to: Amaral i Magalhães, op. cit., note 29, p. 81
} 
tion, distribution and consumption. International trends frequently operate as legitimate sources for national politics. ${ }^{30}$

Zsifkovits also talks about the concept of globalisation and distinguishes between the narrow interpretation of the concept of globalisation (focused on the economy) and wider interpretation of the same concept (the process that includes all the areas of life and consistently transcends national borders). ${ }^{31}$

However, some authors by connecting the globalisation process with hyper-capitalism, emphasize that the same terms have become the subject of numerous debates in an attempt to explain modern movements and global occurrences (current debates regarding the globalisation process refer to globalisation as a phenomenon characteristic for triangle Japan - USA - EU). Furthermore, it is claimed that globalisation and hyper-capitalism are a consequence and instruments of the governing theory of neoliberalism (whose basic idea was to separate and limit the influence of government politics from corporation administration, from supranational or transnational organisations and consequently subject and instrumentalise them to achieve goals and interests of financial capital separated from real economy).$^{32}$ However, it is certain that globalisation truly does represent a set of economic, social, political and cultural processes that lead to a greater connection and co-dependence between particular parts of the world..$^{33}$

Milardović's approach in clarifying two basic terms - globalisation and globality is considered quite interesting. Milardović emphasizes that globalism means "that global market is suppressing or compensating for political action, that is, ideology of authority over global market, the ideology of neoliberalism" while globality refers to the attitude that "we have been living in one global society for quite long... and that no country or community can be isolated. In this way various economic, cultural, political forms collide..." ${ }^{34}$

30 Ibid. More about the concepts of public administration in: Marčetić, G., Upravljanje ljudskim potencijalima u javnoj upravi, Suvremena javna uprava, Zagreb, 2007, pp. 43-67

31 Zsifkovits' contribution to the topic of globalisation refers to economic globalisation and its ethical viewpoints (this way he processes the issue of globalisation process, its direction towards international general goods, its influence on unemployment and similar). More in: Zsifkovits, V., Globalizacija i etika, in: Baloban, S. (ed.), Gospodarsko - socijalni izazovi u tranzicijskim zemljama, Institut drustvenih znanosti Ivo Pilar, Zagreb, 2001, p. 107

32 This way Kulić explains the notion of hyper-capitalism as a concentrated term having the furthest range in neoliberal doctrine, system philosophy and politics. See in: Kulić, S., Neoliberalizam kao socijaldarvinizam, Rat za dominaciju ili bolji svijet, Prometej, Zagreb, 2004, p. 170; 172

33 Kalanj, R., Globalizacija i postmodernost, Politička kultura, Zagreb, 2004, p. 62

34 Milardović, A., Globalizacija, Pan liber, Osijek - Zagreb - Split, 2001, pp. 64-65 
The United Kingdom and New Zealand were the first to introduce neoliberal politics and have later been copied by other countries as examples for international agencies. In addition, Ball claims that "in certain contexts this project brings ideas and creates a sort of cultural and political dependence leading to devaluation or denial of feasibility of local solutions." ${ }^{35}$

Moreover, Levin (1988) interprets the other version by using medical metaphor. Levin compares political transfers of current education with the spread of diseases, whereby international experts, political entrepreneurs and organisation representatives are those selling "wonderous hand-made solutions to national problems, infected agents who move from country to country seeking adequate hosts to infect". ${ }^{36}$ From the cultural and economic point of view, globalisation presents a concept that can enrich the analysis of development trends of higher education but is not the only factor determining the development. Globalisation is recurrently presented as a fact or a process which cannot be avoided: as the only way to general prosperity, which is connected to erosion of national borders and awakening of the role of supranational governments. ${ }^{37}$

Some authors claim that globalisation ${ }^{38}$ does not mean that national variations do not stay strong nor does it question homogenous nature of global culture and its models. The ever-growing transnational influence does not destroy the power of connections between the countries, nor their sovereignty. Boyer and Drache, by using the instability of the financial market as an example of administration limit in absence of state intervention, conclude that "the idea of global market will completely erode legality". ${ }^{39}$ On the other hand, the logic of globalisation tolerates and demands the promotion of cultural (and if possibly even political) divergence and diversity. Globalisation will be built on diversity and should operate according to patterns that seem paradoxical - both global as well as decentralised - forms of social organisation conveying powerful images of elections, freedom and diversity. ${ }^{40}$

The biproduct of globalisation of neoliberal economy is the appearance of "the new regionalism" (Acharya, 2001) whose results vary slightly and are at times even

\footnotetext{
35 Ball 1998: 123, according to: Amaral; Magalhães, op. cit. note 31, p. 82

36 Ibid.

37 Porter 1999: 31, according to: Ibid.

38 About the implications of globalisation and the occurences accompanying it, read more in: Pusić, E., Nauka o upravi, Školska knjiga, Zagreb, 2002, p. 4

39 Boyer i Drache 1996: 8, according to Amaral i Magalhães, Epidemiology and the Bologna Saga, loc. cit.

40 Jones, 1998: 149-150, according to: Cf. ibid., pp. 82-83
} 
conflictive. Yet, so far, only the European Union has initiated visible intervention within the systems of higher education. ${ }^{41}$

\section{CHANGES WITHIN THE SYSTEM OF HIGHER EDUCATION}

The word change brings both positive and negative implications. More specifically, the changes that have been happening, and are still happening today, within the system of higher education ${ }^{42}$ are frequently connected to certain drawbacks which become difficult to correct after a while. Every change for the better is more than welcome. However, oftentimes bad changes are introduced which is negatively reflected on the higher education system. It is not justified to change the higher education system only for the purposes of causing the change itself. What is more, these changes lead to passivation of almost all participants of the system while at the same time causing users' dissatisfaction (the priority is users' satisfaction). How should the higher education system be improved? ${ }^{43}$

In the White Paper on the Future of Europe - considerations and scenarios for EU-27 by 2025 it is said that the European Commission will contribute to debates, among others those regarding exploiting the development of social dimensions of citizens, as well as those regarding exploiting the globalisation process. ${ }^{44}$

Beukel claims that the higher education politics has for a long time not been a part of the European agenda and that the deeper integration and cooperation in the agenda of higher education or even European Higher Education Area (EHEA) have seemed unthinkable, whereas the wider European corporation has been limited to programmes of EU mobilities (Beukel, 2001). The situation has significantly

41 Mittelman, 1996: 6, according to: Ibid.

42 The presented viewpoint of higher education as public service is closely related to the definition that public services are definitely "the key element of social state and are provided by public institutions and corporations whose founders are the state, local and regional units." Public services are primarily regarded as social services such as education, healthcare, culture, social care and others. Recently, a noticeable trend of implementation of the process of privatisation, commercialisation and agentification of public services has been present. Koprić et al. also say, that when discussing public services, the emphasis is on subsidiarity. Liberalisation refers to "forming a sectorial market in which a particular type of public services is ensured based on market competition", by privatisation, a public organisation is sold to a private owner. More in: Koprić et al., op. cit., note. 1, pp. 7-8

43 When it comes to changes that might eventually occur in the area of higher education, one particularly important variable should be mentioned, that being the organisational structure, which according to Buble, does not present an independent variable, but is rather under the influence of numerous factors, from which the following will be pointed out: environment, strategy, technology and size. More in: Buble, M., Osnove menadžmenta, Sinergija nakladništvo d.o.o., Zagreb, 2006.

44 Available on: [https://ec.europa.eu/commission/sites/beta-political/files/bijela_knjiga_o_buducnosti_europe_hr.pdf], accessed 14. March 2020 
changed since 1999. Ninety-nine ministers responsible for higher education signed the Bologna declaration marking the beginning of the so-called Bologna process. The ministers have agreed to found EHEA by 2010. Despite legally non-binding and intergovernmental character, different reforms related to the process have been initiated by all the countries who signed the declaration showing at the same time "(..) that the governments have developed policies that correspond with the European agenda according to convergent systems of higher education." 45 The noticeable degree of national changes within the system of higher education still significantly varies. ${ }^{46}$

Other documents based on the Bologna declaration are the Prague Communique from 2001, the Berlin Communique from 2003 and the Bergen Communique from 2005. The common feature of all the documents is that they strive to enhance the social dimension in higher education (equal opportunities to enrol in and finish a preferred university, achieving balance between economic competitiveness and social cohesion within the European higher education system). ${ }^{47}$

In conclusion, the significance of the European area is crucial for political circles, all the parties in the higher education system as well as for the industrial sector. Empowering and enriching this area can only result in satisfaction for all the interested parties. The recommendation is that all working on improvement of the higher education system follow the European Commission`s referral to enable access to the best education and training for youth as well as to open new workplaces for youth across Europe. The Commission encourages creating the European area of high education and highlights the following: studying abroad should become general practice, school and university qualifications should be acknowledged in the entire EU, knowledge of two languages should become a standard, all students should have equal access to education regardless of their socioeconomic status,

45 Huisman and Wende 2004: 355, according to Heinze T.; Knill, C., Analysing the differential impact of the Bologna Process: Theoretical considerations on national conditions for international policy convergence, Higher Education, 56, Issue 4, Springer, 2008, pp. 493-494

46 Luijten-Lub et al., 2005: 158; Witte, 2006, according to: Ibid. About the agencies as parts of public service more in: Mecanović, I. et al., Državne (regulatorne) i javne agencije, Sveučilište Josipa Jurja Strossmayera u Osijeku, Pravni fakultet u Osijeku, pp. 61-79. The analysis of legal acts regarding the Agency for Science and Higher Education is available in the prior mentioned book written by Mecanović, I. et al., p. 116

47 More in: Puzić, S. et al., Socijalna dimenzija "Bolonjskog procesa“ i ne (jednakost) šansi za visoko obrazovanje: neka hrvatska iskustva, Sociologija sela, vol. 44, no. 2-3, 2006, p. 244, [http://idiprints.knjiznica. idi.hr/581/1/SS\%202006_2-3\%20\%20Puzi\%C4\%87.pdf], accessed 29. May 2020 
all citizens should become more aware of their own identity, European cultural heritage and its diversity. ${ }^{48}$

\subsection{Organisational changes within the system of higher education}

Changing the organisational structure is a process "of remodelling the existing organisational structure with the aim of improving organisational efficacy (changes may refer to organisational hierarchy, level of responsibility of different organisation members and similar), whereby the following factors are to be taken into consideration: the involved participants; what needs to be changed; what type of change should be introduced; individuals affected by the change and the estimate of the change". ${ }^{49}$ Most important organisational changes of higher education system on strategic level comprise of "diversification" of higher education and organisational and administrative changes on universities which optimise the relationship between integration and decentralisation within the framework of a single university. On the organisational level "diversification" of higher education ${ }^{50}$ refers to introducing programmes of different duration, that is development of binary system in higher education (establishing two subsystems of higher education). This concept is compliant with the development trend of European higher education and in Croatia it was introduced in 1993 by Science and Higher Education Act. Higher education in Croatia is, therefore, achieved through undergraduate and graduate professional study programmes. There are significant problems in both development of undergraduate studies and in improving organisation and administration of universities. ${ }^{51}$

48 More in: Europska komisija, Obrazovanje i izobrazba, Europski prostor obrazovanja, [https://ec.europa. eu/education/education-in-the-eu/european-education-area_hr], accessed 29. May 2020

49 Certo, S. C.; Trevis Certo, S., Moderni menadžment, Zagrebačka škola ekonomije i menadžmenta, MATE d.o.o., Zagreb, 2008, p. 300; 302

50 More about higher education as public service in: Dujmović, J., Visoko obrazovanje kao javna služba, doctoral thesis, Zagreb, 2014. It is the author`s recommendation to see the entire research about the successfulness of reforms in higher education in Croatia implemented for the purposes of the author's doctoral dissertation. The mentioned research has included all the components within the framework of Josip Juraj Strossmayer University in Osijek referring to the fact that surveys have been conducted on a relevant number of teachers, assistants on one hand and students on the other. It is recommended to study the set hypotheses/sub-hypotheses as well as the results of the conducted research that have led to a complete or partial confirmation of the mentioned hypotheses. More about the empirical research in the prior mentioned source: pp. 207-247

51 Cf. ibid, p. 75. More about managerial styles, that is interaction between the society and managers in: Pende, H., Moć neetičkog poslovanja - organizacijska kultura u Hrvatskoj, Hrvatska sveučilišna naklada, Zagreb, 2008, pp. 51-52. One should see the analysis of administrative reforms in transitional countries in: Marčetić, G., Javni službenici i tranzicija, Suvremena javna uprava, Zagreb, 2005, pp. 99-117 
Public - private partnership (hereinafter: PPP) is a long-term contractual relationship between public and private partners, subject of which being the construction and/or reconstruction and maintenance of public building with the purpose of providing public services from the jurisdictional framework of public partner. ${ }^{52}$ Numerous domestic and foreign scientific papers have been written on the issue of public - private partnership, whereby the main subject matter of debates regarding implementation of PPP within the higher education system are frequently matters such as: is implementation of PPP within the higher education system necessary?, what are the advantages and disadvantages of implementation of PPP, is the implementation of PPP within the higher education system useful or harmful to the entire system? and similar.

When analysing the term PPP, stakeholders play a very important role. Stakeholders are influential interest groups relevant for a system. In the analysis of influential interest groups Tipurić defines stakeholders as "influential interest groups within a corporation (or any other organisation) and around it. Influential interest groups are individuals, groups and organisations, as well as coalitions of individuals, groups and organisations within and outside of the corporation, who have certain rights, demands or interests regarding the corporation. They express them due to the special relationship, taking in the process lesser or greater risk, based on their connection to the corporation. ${ }^{53}$ Tipurić considers that the providers of critical resources, shareholders, employees, buyers and suppliers, large creditors are primary stakeholders. This, however, still does not mean the organisation should consider the interests of its primary stakeholders equal (their interest are direct and tangible and they are crucial for the organisation's existence and activities) while secondary stakeholders are those who indirectly influence the organisation and their status is frequently determined by their activity (their interests are indirect and remote such as those of end consumers, competition, state on different levels, public, society as a whole, media etc.). ${ }^{54}$ In literature, the key reason for applying PPP is frequently the effectiveness achieved by its implementation, but in any case the traditional values provided by traditional (social) way of public service providing should not be neglected. PPP does in fact change the traditional relationship "state service delivery - citizens" into the relationship "private service delivery - users (buyers) consumers". According to the Guidelines for successful PPP application,

\footnotetext{
52 Definition taken from the Public - Private Partnership Act, Official Gazette No. 78/12, 152/14, $114 / 18$

53 The mentioned analysis is available on p. 21: [http://www.efzg.unizg.hr/UserDocsImages/OIM/dhruska/2014-2-\%20Situacijska\%20analiza\%20-\%20okolina\%20i\%20SWOT.pdf], accessed 21. March 2020

$54 \quad$ Ibid., p. 22
} 
every project financed by PPP should meet the following criteria: public and private sector cooperate based on public contractual relations, the concept of sharing the responsibility, costs and risks should be stated in the contract, project arranged by PPP must simultaneously ensure both public interest and commercial goal of both PPP partners, both PPP partners should expect higher results for the same price or the same results for a lower price and each partner keeps its own identity and responsibility. ${ }^{55}$

Stainback claims that when providing public service there are four different types of mergers: a) traditional process or public project - public sector is the owner of the project; it is responsible for financing of the project, for creating the project outline; it controls the project and takes its risks; b) private project with public participation; c) public - private partnership - public and private sector share the ownership, risk management and responsibility for the project as well as its finances; d) public + public-private partnership - the agreement in which more local units of the public sector signs contract with a private partner. ${ }^{56}$

PPP is the product of the last third of the $20^{\text {th }}$ century presenting a form of participation of the private sector in public affairs (in some administrative systems it is also known as private financial initiative) which is mostly used for financing construction and managing large infrastructural objects. It is a long-term agreement (e.g. in Croatia PPP can last between five and forty years) after which the constructed infrastructure belongs to the public sector. Various PPP models can be reduced to two basic models - institutional or status in which a combined trade association is founded and contractual in which such association is not founded. In Croatia, private partner participating in the PPP project is obligated to establish a special trade association exclusively for realisation of PPP project (special purpose association) with whom then public partner signs the contract about PPP. Relevant elements of strategic public projects through PPP are ensuring public benefit for invested means, quality contract elaboration about PPP that needs to possess adequate mechanisms to ensure realisation of public aims and protection of public interest, comparison of costs and benefit, selection of optimal private partner, key risks identification and allocation and similar. Drawbacks of PPP arise from the preparation of relevant elements upon which successful realisation of PPP is based, such as insufficiently prepared mechanisms for public interest protection, deficient risk identification and allocation, too large costs etc. ${ }^{57}$

\footnotetext{
55 European Commission, 2003, according to: Šimović J. i dr., Javno-privatno partnerstvo kao nefiskalni instrument financiranja javnih interesa, Hrvatska javna uprava, vol. 7, no. 1, 2007, p. 173; 181

56 Stainback, 2000:16, according to: Cf. ibid., pp. 181-182

57 More in: Koprić et al., op. cit., note 22, pp. 245-246
} 
In his article Molnar analyses the segment of public-private partnership in higher education by stating basic advantages and drawbacks of this model. In addition, Molnar studies the relationship between the government, university and the industrial sector. Basic benefits are increased employment rate of well-educated youth and increase in employability of graduates and postgraduates. ${ }^{58}$ On the other hand, the main drawbacks would be unequal ability of educational institutions for cooperation with private partners (the advantage is given to faculties of technology and faculties of natural sciences). ${ }^{59}$

The model of public-private partnership within the system of higher education is welcome unless it disturbs the principle of equal educational opportunities. The emphasis should be on cooperation between the three participants: government, university and the industrial sector. This would finally make the model desirable for all who decide to take part in the higher education system regardless of their role in it.

\section{CONCLUSION}

General approach to higher education is variable in nature which will, in author's opinion, cause the debate between public and private to last for quite a long time. Since the processes of privatisation and commercialisation are becoming more noticeable, perception of higher education as public service is changing accordingly. Marginson's definition of public goods as those goods that are available to wider population and are trying to stay competitive is therefore completely acceptable.

There is a significant need for an informal approach which would present an adequate combination of the public/private approach. Sectors as higher education, that have been analysed in this paper, are in their essence neither public nor private and can be presented in both ways. This means that the area of higher education can be exclusively public, private or a combined area. One combined model of public and private is preferred worldwide while highlighting the fact that public and private must form a positive sum.

It is evident that globalisation process comprehended as expansion and acceleration of global connections largely influences the development of higher education.

\footnotetext{
58 More in: Thune, 2009 i 2010; Carayannis, Alexander and Ioannidis, 2000; Enders and Jongbloed, 2007, according to: Molnar, T., Javno - privatno partnerstvo u visokom obrazovanju kao promotor razvoja tržišno primjenjivog znanja, Andragoški glasnik: glasilo Hrvatskog andragoškog društva, vol. 17, no. 2 (31), Zagreb, 2013, pp. 160, [https://hrcak.srce.hr/116178], accessed 29. May 2020

59 Thune, 2009, according to: Ibid.
} 
The White Paper on the Future of Europe - considerations and scenarios for EU27 by 2025 supports this fact.

Public - private partnership is welcome within the system of higher education, however, without the risk of losing basic values upon which, this extremely important segment of every citizen's life, is based. Traditional values should be preserved within the system while aiming for responsibility for the achieved results. It is concluded that the cooperation between the three participants: government, universities and industrial sector is relevant, but only if it contributes to financial and innovation progress of the higher education system (at the same time achieving economic growth). In addition, the following questions need to be answered: does PPP present the transitional form to total privatisation of higher education; is promoting PPP model undermining social values and similar. Once the answers are found, the direction in which to head will be known, presuming this direction at the same time represents "the right way".

Finally, the following conclusion can be made:

1. since there are different interpretations of the notion public/private a precise and specific attitude regarding categorisation of higher education system should be formed without losing the fundamental comprehension of higher education as public service,

2. encourage and support the values which will in the foreseeable future improve the public services (e.g. improving the quality of higher education in Croatia),

3. accept and follow the globalisation processes by supporting the values represented by the majority of the developed countries,

4. find an adequate model to follow (values and techniques),

5. enable spontaneous changes within the higher education system which are supported by political and other interested parties,

6. ensure political support and continuity for all the changes that are occurring (political determination),

7. identify the advantages and disadvantages of the public-private partnership model and apply it within the Croatian higher education system,

8. follow the world trends in the area of higher education,

9. notify all the participants and interested parties about the current changes within the higher education system framework, 
10. observe all the occurring changes from the perspective of the European context and encourage the implementation of values which will result in improvements of higher education as public service without contributing to forgetting the main aspects of the interpretation of higher education as public service.

The presented analysis including the theoretical background should in the future be used for conducting empirical research with the purpose of validating or disputing the given assumptions. The research results would greatly contribute to administrative science especially in the segment of public services while supporting the notion of higher education as public service.

\section{REFERENCES}

\section{BOOKS AND ARTICLES}

1. Amaral A.; Magalhães A., Epidemiology and the Bologna Saga, Higher Education, 48, Issue 1, Springer, 2004, pp. $79-100$

2. Antić, T., Ustrojstvo i djelokrug javnog sektora, Pravni fakultet Sveučilišta u Rijeci, Rijeka, 2014

3. Bebek, B., Kolumbić, A., Poslovna etika, Sinergija, Zagreb, 2000

4. Blažević, R., Upravna znanost-kompendij, Pravni fakultet Sveučilišta u Rijeci, Rijeka, 2004

5. Buble, M., Osnove menadžmenta, Sinergija nakladništvo d.o.o., Zagreb, 2006

6. Certo, S. C.; Trevis Certo, S., Moderni menadžment, Zagrebačka škola ekonomije i menadžmenta, MATE d.o.o., Zagreb, 2008

7. Cvitan, O., Upravna organizacija, Veleučilište u Šibeniku, Šibenik, 2008

8. Dujmović, J., Visoko obrazovanje kao javna služba, doctoral thesis, Zagreb, 2014

9. Heinze T.; Knill, C., Analysing the differential impact of the Bologna Process: Theoretical considerations on national conditions for international policy convergence, Higher Education, 56, Issue 4, Springer, 2008, pp. 493-510

10. Kalanj, R., Globalizacija i postmodernost, Politička kultura, Zagreb, 2004

11. Koprić, I., et al., Upravna znanost, Javna uprava u suvremenom europskom kontekstu, Pravni fakultet Sveučilišta u Zagrebu, Studijski centar za javnu upravu i financije, Biblioteka Suvremena javna uprava, Knjiga br. 25, Zagreb, 2014

12. Koprić, I., et.al., Europski upravni prostor, Institut za javnu upravu, Zagreb, 2012

13. Kulić, S., Neoliberalizam kao socijaldarvinizam, Rat za dominaciju ili bolji svijet, Prometej, Zagreb, 2004

14. Kursar, T., Smrt „globalizacijske teorije“ ili kraj još jedne revolucije?, Politička misao, vol. 45. no. 1, Zagreb, 2008, pp. 3 - 28

15. Marčetić, G., Javni službenici i tranzicija, Suvremena javna uprava, Zagreb, 2005

16. Marčetić, G., Upravljanje ljudskim potencijalima u javnoj upravi, Suvremena javna uprava, Zagreb, 2007 
17. Marginson, S., The public/private divide in higher education: A global revision, Higher education, vol. 53, London, 2007, pp. 307 - 333

18. Mecanović, I., et al., Državne (regulatorne) i javne agencije, Sveučilište Josipa Jurja Strossmayera u Osijeku, Pravni fakultet u Osijeku, 2012

19. Milardović, A., Globalizacija, Pan liber, Osijek - Zagreb - Split, 2001

20. Pende, H., Moć neetičkog poslovanja - organizacijska kultura u Hrvatskoj, Hrvatska sveučilišna naklada, Zagreb, 2008

21. Pusić, E., Nauka o upravi, Školska knjiga, Zagreb, 2002

22. Sandler T., Intergenerational public goods : Strategies, efficiency and institutions, in: Kaul, I.; Grunberg, I.; Stern, M. (eds.), Global Public Goods: International cooperation in the 21st century. New York: Oxford, 1999, pp. 20-50

23. Šimović J. et al., Javno-privatno partnerstvo kao nefiskalni instrument financiranja javnih interesa, Hrvatska javna uprava, vol. 7, no. 1, 2007, pp. 171-201

24. Tudor, G., Srića, V., Menadžer i pobjednički tim, MEP Consult i Croman, Zagreb, 1996

25. Zsifkovits, V., Globalizacija i etika, in: Bloban, S. (ed.), Gospodarsko - socijalni izazovi u tranzicijskim zemljama, Institut društvenih znanosti Ivo Pilar, Zagreb, 2001

\section{LIST OF NATIONAL ACTS}

1. The Constitution of the Republic of Croatia, Official Gazette No. 56/90, 135/97, 08/98, 113/00, 124/00, 28/01, 41/01, 55/01, 76/10, 85/10, 05/14

2. Act on Quality Assurance in Science and Higher Education, Official Gazette, No. 45/09

3. The Science and Higher Education Act, Official Gazette No. 123/03, 198/03, 105/04, 174/04, 02/07, 46/07, 45/09, 63/11, 94/13, 139/13, 101/14, 60/15, 131/17

4. Public -Private Partnership Act, Official Gazette No. 78/12, 152/14, 114/18

\section{WEBSITE REFERENCES}

1. Agency for Science and Higher Education, [https://www.azvo.hr/hr/], accessed 19. March 2020

2. Europska komisija, Obrazovanje i izobrazba, Europski prostor obrazovanja, [https://ec.europa. eu/education/education-in-the-eu/european-education-area_hr], accessed 29. May 2020

3. Kaul, I., Global Public Goods, A concept for framing the Post - 2015 Agenda, [https://www.ingekaul.net/wp-content/uploads/2014/01/Internetfassung_DiscPaper_2_2013_Kaul1.pdf], accessed 29. May 2020

4. Petak, Z., Je li obrazovanje javno dobro?, [http://www.rsp.hr/ojs2/index.php/rsp/article/viewFile/877/773], accessed 26. May 2020

5. The European Commission $\operatorname{COM}(2017)$ 2025, 1.3.2017. [https://ec.europa.eu/commission/sites/beta-political/files/bijela_knjiga_o_buducnosti_europe_hr.pdf], accessed 14 . March 2020

6. Tipurić, D., Situacijska analiza (1) - analiza makro okoline i analiza korporativnoga upravljanja (drugo predavanje), 24.2.2014. [http://www.efzg.unizg.hr/UserDocsImages/OIM/ 
dhruska/2014-2-\%20Situacijska\%20analiza\%20-\%20okolina\%20i\%20SWOT.pdf], accessed 21. March 2020

7. Đulabić, V., Socijalne službe u konceptu službi od općeg interesa, Revija za socijalnu politiku, vol. 14, no. 2, Zagreb, 2007, pp. 137 - 162, [https://hrcak.srce.hr/30325], accessed 25. May 2020

8. Menger, M., Razvoj shvaćanja “javnosti” organizacija u organizacijskoj teoriji, Zbornik Pravnog fakulteta Sveučilišta u Rijeci, vol. 39, no. 2, Rijeka, 2018, pp. 989 - 1009, [https:// hrcak.srce.hr/204643], accessed 25. May 2020

9. Molnar, T., Javno - privatno partnerstvo u visokom obrazovanju kao promotor razvoja tržišno primjenjivog znanja, Andragoški glasnik: glasilo Hrvatskog andragoškog društva, vol. 17, no. 2. (31), Zagreb, 2013, pp. 145-164, [https://hrcak.srce.hr/116178], accessed 29. May 2020

10. Petak, Z., Upravljanje prirodnim resursima kao zajedničkim dobrima: teorijski pristup razlikovanju javnih dobara $i$ zajedničkih resursa, Forum za javnu upravu - izazovi upravljanja javnim dobrima, Friedrich-Ebert-Stiftung, ured za Hrvatsku, Institut za javnu upravu, Zagreb, 2019, [https://iju.hr/Dokumenti/fju_17.pdf], accessed 26. May 2020

11. Puzić, S. et al., Socijalna dimenzija „Bolonjskog procesa“ i ne (jednakost) šansi za visoko obrazovanje: neka hrvatska iskustva, Sociologija sela, vol. 44, no. 2-3, 2006, pp. 243-260, [http:// idiprints.knjiznica.idi.hr/581/1/SS\%202006_2-3\%20\%20Puzi\%C4\%87.pdf], accessed 29. May 2020 